\title{
RADIOCARBON DATES OF THE INSTITUTE OF ARCHAEOLOGY III*
}

\section{P M DOLUKHANOV, A A SEMYONTSOV, Yu S SVEZHENTSEV, V I TIMOFEYEV, Ye N ROMANOVA, and N S MALANOVA}

Institute of Archaeology, Leningrad Branch, Academy of Sciences, USSR

This list contains radiocarbon dates of archaeologic samples of wood, charcoal, and peat measured between 1967 and 1973, analyzed by the Laboratory of the Institute of Archaeology, Leningrad Branch, USSR Academy of Sciences. The samples measured include charcoal from cultural strata and hearths, wood from kurgans and cultural strata, peat, etc, coll from various archaeologic sites by Soviet scientists, as well as a series from Dashly site, Afghanistan.

In all cases benzene was used for counting. Benzene synthesis was attained by means of acetylene trimerization with a vanadium-aluminasilica catalyst described elsewhere (R, 1970, v 12, p 130).

Northwest European USSR: Mesolithic, Neolithic and Bronze age sites

\section{Latvian SSR}

\section{Osa series, Lubana Lowland}

Osa sites are in $\mathrm{E}$ part of Lubana depression, Balvy Raion [ca $57^{\circ} 00^{\prime}$ $\mathrm{N}$ Lat, $27^{\circ} 00^{\prime} \mathrm{E}$ Long]. Archaeol study by F A Zagorskis (1967). Presumed age: Early Neolithic, 4th millennium BC.

\section{LE-961. Osa}

$5880 \pm 80$

Wood, depth 1.2 to $1.3 \mathrm{~m}$.

3930 BC

LE-962. Osa

Wood, depth 1.4 to $1.5 \mathrm{~m}$. Comment: samples coll by P M Dolukhanov, Inst Archaeol, Acad Sci, USSR, Leningrad, and F A Zagorskis, Inst Hist, Latvian Acad Sci, Riga; subm by P M Dolukhanov. Samples from deposits containing early Neolithic assemblage of Osa type pottery. Dates correspond weil with earlier date of same assemblage (LE-850: $5730 \pm 50$;

* Thanks are extended to G V Sipovski, Head, Laboratory of Archaeological Technology, Institute of Archaeology, Leningrad, for editing the present list, to $\mathbf{V} P$ Ulyanov for assistance in the preparation and treatment of samples, and to $\mathbf{V} \mathbf{M}$ Molebnikov for maintaining the electronic equipment.

The English translation was received through Mtislav Keldysh, Pres, Academy of Sciences, USSR, by Henry Field, Coconut Grove, Miami, Florida, and was edited by Edith M Shimkin, Assoc, Russian and East European Center, University of Illinois at Urbana-Champaign. The assistance of the Russian and East European Center, University of Illinois, in preparation of the translated manuscript is gratefully acknowledged. The original Russian text has been placed on Microfiche by Field Research Projects, Coconut Grove, Miami, Florida. Brackets refer to inserts by Edith M Shimkin. Oblast' has been abbreviated Obl.

Radioactivity was measured on a one-channel scintillation counter the parameters of which were stabilized by highly stable light impulses. Forced stabilization of the counter window in the ${ }^{14} \mathrm{C}$ spectrum increased the accuracy of measurement, lowering the apparatus error from $1 \%$ to $0.3 \%$. The modern standard used is correlated with NBS oxalic acid with an error not exceeding $1 \%$. 
R, 1972, v 14, p 338). Palynologically, dated layer corresponds to maximum of broad-leaved pollen species--Atlantic 1 pollen zone, analyzed by G M Levkovskaya. Underlying Mesolithic cultural layer of same site was dated: Bln-770: $7186 \pm$ 160; LE-811: $6960 \pm 80$ and LE-812: $6760 \pm$ 80; LE-810: $6580 \pm 70$ (R, 1972, v 14, p 338).

\section{LE-903. Zveysalas site, Rezekne Rayon}

Wood from cultural layer of Zveysalas site. Archaeol date: Early Neolithic, 4th to beginning 3rd millennium BC. Coll and subm by I A Loze, Latvian Acad Sci, Inst Hist, Riga. Comment: date is far too recent; stratigraphic distortion is possible.

\section{LE-867. Piestina, Rezekne Rayon}

$$
4250 \pm 50
$$

2300 BC

Peat from cultural layer of Piestina site $\left[56^{\circ} 55^{\prime} \mathrm{N}\right.$ Lat, $27^{\circ} 00^{\prime} \mathrm{E}$ Long]. Comment: site excavated by F A Zagorskis. Cultural material attributed to Developed Neolithic, 3rd millennium BC. Date roughly agrees with earlier dates: LE-750: $4670 \pm 150$; LE-748: $4520 \pm 120$ (R, 1972, v 14, p 338). Palynologically, layer corresponds to Atlantic 2 Sub-Boreal 1 pollen zone boundary, analyzed by G M Levkovskaya.

\section{Sārnate series, Ventspils Rayon}

\section{LE-902. Sārnate}

$$
1220 \pm 80
$$

Charcoal from dwelling site (Vankina, 1970). Presumed age: Neolithic, 3rd millennium вс. Comment: date is much too recent; contamination possible. Other wooden dwellings from same site dated: LE-814: $4510 \pm 110(\mathrm{R}, 1972, \mathrm{v} 14, \mathrm{p} 340)$; Bln-769: $4640 \pm 100(\mathrm{R}, 1970$, v 12, p 417); TA-26: $4700 \pm 250(\mathrm{R}, 1966, \mathrm{v} 8, \mathrm{p}$ 434); TA-24: $4490 \pm 250$ (ibid); TA-265: $4630 \pm 70(\mathrm{R}, 1971, \mathrm{v} 13, \mathrm{p} 82)$.

\section{LE-899. Sārnate}

$$
8900 \pm 90
$$

Hypnum peat, depth, $3.1 \mathrm{~m}$.

$$
6950 \mathrm{BC}
$$

\section{LE-900. Sārnate}

$7860 \pm 60$

Sapropel, depth, 2.2 to $2.4 \mathrm{~m}$.

\section{LE-901. Sārnate}

$7570 \pm 90$ $5620 \mathrm{BC}$

Carex-Hypnum peat, in contact with sapropel, depth, 2.1m. Samples subm by P M Dolukhanov. Comment: dates refer to Holocene history of Baltic Sea. LE-899 dates regression between 2 phases of Ancylus Lake; LE-900 and -901 determine beginning of regression preceding onset of Littorina Sea transgression (Dolukhanov, 1973).

\section{LE-868. Lagazha, Balva Rayon}

Wood from cultural layer. Presumed date: Forest Zone Early Bronze, 2nd half to end of 2 nd millennium BC. Coll by I A Loze; subm by P M 
Dolukhanov. Comment: age more recent than dates for other sites with corded ware in Latvia: Abora, LE-671: $3870 \pm 70$ (R, 1970, v 12, p 133); LE-749: $3860 \pm 100(\mathrm{R}, 1972$, v 14, p 339); in Lithuania, Šventoji, upper layer, LE-865, below.

\section{Lithuanian SSR}

\section{LE-865. Šventoji (Shvyentoyi) site, Kretinga Rayon 1930 BC}

$$
\mathbf{3 8 8 0} \pm \mathbf{8 0}
$$

Wood from upper layer. Comment: Šventoji site is being excavated by R K Rimantene (1970), Inst Hist, Lithuanian Acad Sci, Vilnius. Samples coll and subm by $\mathrm{P}$ M Dolukhanov. Upper layer of site previously dated: LE-835: $3860 \pm 50$ (R, 1972, v 14, p 341); Vs-22: $4100 \pm 100$ (Šulija, 1968); TA-246: $4120 \pm 80$.

Lower layer dated: LE-839: $4100 \pm 60$; LE-904: $4225 \pm 70$ (R, 1972, v 14, p 341); TA-247: $4440 \pm 90$; Vs-23: $4400 \pm 55$ (Šulija, 1968). For General Comment, see R, 1972, v 14, p 340-341.

\section{Belorussian SSR}

\section{LE-960. Zatsen'ye, Minsk Obl}

$\mathbf{5 4 5 0} \pm 75$ 3500 BC

Peat from cultural layer, Zatsen'ye site. Depth, $1.9 \mathrm{~m}$. Presumed age: Early Neolithic, 4th millennium BC. Coll and subm by M M Chernyavski and P M Dolukhanov. Comment: pottery assemblage of Zatsen'ye site, according to Chernyavski (1971), belongs to Early Neolithic. $C f$ dates for Osa, Early Neolithic, above.

\section{Krivina peat bog series, Vitebsk Obl}

Krivina peat bog containing several Late Neolithic and Bronze age sites is situated in Beshenkovichi Rayon. Excavations by M M Chernyavski (1971).

\section{LE-936. Osovets II}

Charcoal from base of cultural layer. Coll by M M Chernyavski; subm by N N Gurina, Inst Archaeol, Acad Sci, USSR, Leningrad.

\section{LE-1062. Krivina I}

Wood from cultural layer; depth, 1.5 to $1.6 \mathrm{~m}$. Coll and subm by $\mathrm{M}$ M Chernyavski and P M Dolukhanov.

\section{LE-1063. Krivina I}

$$
\begin{gathered}
2660 \pm 50 \\
710 \mathrm{BC}
\end{gathered}
$$

Peat, depth, 0.7 to $0.6 \mathrm{~m}$; above cultural layer. Coll and subm by $\mathrm{M}$ M Chernyavski and P M Dolukhanov. Comment: archaeol dating for Krivina and Osovets is developed (Late) Neolithic, 3rd to beginning of 2nd millennium Bc. Dates obtained for both sites that have closely related archaeol material agree well; also with previous dating for Krivina I: LE-757: $3880 \pm 60(\mathrm{R}, 1972$, v 14, p 337). For Osovets II, roots in upper portion of cultural layer were dated: LE-756: $3350 \pm 60$ (ibid). 
Flint mines series, Grodno Obl

Samples from prehistoric flint mines in W Belorussia, Volkovyssk Rayon. Excavations by N N Gurina. Coll and subm by N N Gurina.

LE-915. Krasnoye Selo

$3510 \pm 110$ face.

$3350 \pm 80$

LE-913. Karpovtsy 1, 2, 4

1400 BC

Charcoal from Shaft 1, depth $1 \mathrm{~m}$; Shaft 2, depth $1.10 \mathrm{~m}$; Shaft 4, depth $0.4 \mathrm{~m}$.

LE-914. Karpovtsy 5

$3490 \pm 70$

Charcoal from Shaft 5 , filling pile hole, $1.7 \mathrm{~m}$ below surface.

LE-1032. Karpovtsy 13

$3000 \pm 30$

Charcoal from Shaft 13, Sec 1, depth, 0 to $0.3 \mathrm{~m}$ below surface. Comment: LE-915 date with earlier dates for Krasnoye Selo flint mines: Shaft 125: LE-799: $3590 \pm 150$ (R, 1972, v 14, p 336); Shaft 12: LE-680: $3370 \pm$ 50 and Shafts 2, 3, 12: LE-639: $3190 \pm 60$ (R, 1970, v 12, p 132). Dates of Karpovtsy mines are roughly contemporaneous with those of Krasnoye Selo mines.

\section{LE-966. Zarech'ye, Brest Obl}

$1135 \pm 105$

Charcoal from cultural layer of Zarech'ye site, Berezovo Rayon. Depth, 0.8 to $0.9 \mathrm{~m}$. Coll and subm by V F Isayenko, Inst Hist, Minsk. Comment: date is much more recent than expected.

\section{LE-965. Litvin, Gomel Obl \\ $230 \pm 45$ \\ AD 1720}

Charcoal from cultural layer of Litvin III, Neolithic site, near Yurevichi village, Kalinkovichi Rayon. Quad D-3-4; depth, 0.6m. Presumed age: 2nd half of 3rd-lst centuries, 2nd millennium вс; Late Neolithic; 4th stage of Dnepr-Don culture, according to V I Isayenko. Coll and subm by V F Isayenko. Comment: date is much more recent than expected.

\section{Kaliningrad Obl, RSFSR \\ LE-848. Serovo (Tsedmar) \\ $4180 \pm 50$ \\ 2230 BC}

Charcoal from Excavation 2, Sq A-2, depth, 0.55 to $0.60 \mathrm{~m}$, lower portion of light-colored sands, Serovo (Tsedmar) site, Ozer Rayon. Presumed age: Neolithic. Coll and subm by P M Dolukhanov. Comment: date supports attribution of site to end of Middle-beginning of Late Neolithic age of E Baltic area (Dolukhanov and Timofeyev, 1970). Palynologically dated to Sub-Boreal zone; analyzed by G M Levkovskaya. 


\section{Naumovo series, Pskov Obl, RSFSR}

Two-layered dwelling site of Naumovo, $\mathrm{N}$ shore of Zhizhika Lake, Kun'ya Rayon. Excavations by A M Miklyayev, State Hermitage Mus, Leningrad (Miklyayev \& Minosyan, 1970); samples coll and subm by P M Dolukhanov; Excavation 1, Sq F 8.

\section{LE-1005. Naumovo}

$260 \pm 50$

Peat, depth, 0.3 to $0.5 \mathrm{~m}$; above cultural layer.

\section{LE-1004. Naumovo}

Peat, depth, 1.3 to 1.5m; Cultural Layer A.

$$
3690 \pm 50
$$

\section{LE-1007. Naumovo}

$4030 \pm 50$

Wood and peat, depth, 2.0 to 2.2m; Cultural Layer B.

\section{LE-1006. Naumovo}

$4920 \pm 50$

2970 вC

Peat, depth, 2.2 to 2.5m; below Cultural Layer B. Comment: LE-1007 date agrees with age of Usvyata IV, Layer B, dwelling site, LE-649: 3920 \pm 90 (R, 1970, v 12, p 135) with which Naumovo, Layer B, has cultural affinities. Dating corresponds to late stage of Usvyata culture in upper reaches of W Dvina R, according to Miklyayev. LE-1004 date, also according to A M Miklyayev, determines age of $\mathrm{N}$ Belorussian culture of corded ware pottery (Miklyayev, 1971).

\section{Zarech'ye series, Vladimir Obl, RSFSR}

Zarech'ye peat bog is situated on flood plain of Sherna R. Excavated by V M Raushenbakh (Dikov \& Raushenbakh, 1970). Samples coll and subm by V M Raushenbakh and P M Dolukhanov.

\section{LE-970. Zarech'ye}

$4580 \pm 50$

Peat, depth, 1.1 to $1.2 \mathrm{~m}$; upper portion of cultural layer.

\section{LE-969. Zarech'ye}

\section{BC}

Peat, depth, 1.4 to $1.5 \mathrm{~m}$; lower portion of cultural layer.

\section{LE-967. Zarech'ye}

Wood, depth, 1.85 to $1.9 \mathrm{~m}$; below cultural layer.

$$
5670 \pm 50
$$

\section{LE-968. Zarech'ye}

\section{$7600 \pm 140$ \\ 5650 BC}

$9888 \pm 95$ 7050 BC

Peat, depth, 2.8 to $2.9 \mathrm{~m}$; below cultural layer. Comment: lower portion of cultural layer contains pottery assemblage of L'yalovo type. LE969 date is close to other dates for sites attributed to L'yalovo pottery: Berendeyevo GIN-112: $5730 \pm 120$; Besovy Sledki: GIN-129: $5430 \pm 50$. 
Upper portion of cultural layer (LE-970) contains pottery of Volosovo type. Cf earlier dates of sites with Volosovo assemblage: Pleshcheyevo IV: GIN-115: $4720 \pm 50$ (R, 1968, v 10, p 428); Ivanovskoye III: GIN-241: $4800 \pm 250$.

\section{LE-941. Chyornaya Maza, Gorki Obl, RSFSR}

$4250 \pm 45$

Charcoal from Neolithic site, Chyornaya Maza, Lyskovo Rayon. Depth, 1.0 to $1.3 \mathrm{~m}$. Subm by L P Zyablin, Inst Archaeol, Acad Sci, USSR, Moscow. Site is attributed to early phase of Volga-Kama Neolithic. Date is younger than expected.

\section{Lugovsk peat bog series, Ul'yanovsk Obl, RSFSR}

LE-950. Lugovsk

Wood, Sample 1, depth, 2.5m.

3050 BC

\section{LE-951. Lugovsk}

$5000 \pm 70$

$\mathbf{3 0 5 0}$ BC

Wood, Sample 2, depth, $2.5 \mathrm{~m}$. Comment: wooden objects (poles with traces of cutting made presumably by stone tools) were discovered in flood plain peat bog of Sviyaga R (Ul-yanovsk Rayon) interpreted as fishing weir. [Other] archaeol material, of corresponding age, was absent. Coll and subm by G M Burov, State Pedagogical Inst, Ul'yanovsk. Dates reveal Neolithic age of construction.

\section{Yavran'ga I series, Arkhangelsk Obl, RSFSR}

Mesolithic dwelling site and prehistoric fishing construction in the Yavran'ga flood plain bog, Kargopol' Rayon. Coll and subm by G M Burov.

LE-853. Yavran'ga-1

$8530 \pm 60$

Charcoal from hearth of Mesolithic dwelling, Sq D-6. Comment: date proves Mesolithic age of site.

LE-854. Yavran'ga G-5

$1260 \pm 50$

$690 \mathrm{BC}$

Wooden stake with incision, depth, 0.5m, Sq G-5.

$2180 \pm 50$

LE-855. Yavran'ga G-4

$230 \mathrm{BC}$

Arched wooden stake, depth, 0.5 to $0.7 \mathrm{~m}$, Sq G-4. Comment: LE-854 and 855 prove prehistoric age of fishing constructions discovered in Yavran'ga peat bog.

\section{Modlona series, Vologda Obl, RSFSR}

Samples from Modlona peat bog dwelling site, Chernozero Rayon. Coll and subm by S V Oshibkina, Inst Archaeol, Acad Sci, USSR, Moscow.

\section{LE-992. Modlona 2}

$3960 \pm 150$

Wood from Test Pit 2, depth, 1.60m.

\section{BC}




\section{LE-993. Modlona 2}

Wood from Test Pit 2, depth, 1.70m.

\section{LE-994. Modlona 2}

Wood from Test Pit 2, depth, $1.10 \mathrm{~m}$. Comment: original excavations by A Ya Bryusov revealed 2 different dwelling places at site (Bryusov, 1952). According to Oshibkina (1966), most finds belong to dwelling site culturally related to Volosovo culture. For undetermined reason, LE-994 was older than LE-992 and -993, contrary to stratigraphic sequence.

\section{Central Russia: Neolithic sites}

\section{Katyn' series, Smolensk Obl, RSFSR}

\section{LE-891. Katyn' 3}

Charcoal from cultural layer, Neolithic site, Katyn' 3, 20km W of city of Smolensk. Depth, 0.4 to $0.5 \mathrm{~m}$.

\section{LE-892. Katyn' 2}

Charcoal from cultural layer, Neolithic site, Katyn' 2, same location as Katyn' 3. Depth, 0.55 to $0 \mathrm{~m}$. Both samples coll and subm by V P Tret'yakov, Inst Archaeol, Acad Sci, USSR, Leningrad. Comment: both dates are much too recent. As established by subsequent excavation, samples obtained from pit of later age, transecting cultural layer.

\section{South Russia, Ukrainian SSR and Moldavian SSR:} Eneolithic and Early Bronze age sites

Charcoal from cultural layer of Matveyev Kurgan II Neolithic dwelling site, right bank Mius R, $3 \mathrm{~km} \mathrm{SW}$ of Matveyev Kurgan village. Depth, 0.6 to $\mathrm{lm}$. Coll and subm by L Ya Krizhevskaya, Inst Archaeol, Acad Sci, USSR, Leningrad. Comment: date is significantly older than those for Eneolithic-Early Bronze sites in neighboring regions of steppe zone (Krizhevskaya, 1971; 1972).

Charcoal, Dwelling 7, under hearth kiln, Tripol'ye B I/B II settlement of Klishchev, Tavrovsk Rayon. Coll and subm by I I Zayets, Vinnitsa Hist Mus (Zayets, 1973). Comment: date agrees with radiocarbon chronology of Tripol'ye culture: Tripol'ye A: Novye Rusesty I: Bln-590: $5565 \pm 590$ (R, 1970, v 12, p 415); Tripol'ye C I: Chapayevka: Bln-631: $4870 \pm 100($ ibid, p 413). 


\section{LE-1054. Danku cemetery, Moldavian SSR}

2650 BC

Charcoal from burial pit, Danku cemetery, Kotovsk Rayon. Depth, $1.2 \mathrm{~m}$. Coll and subm by V A Dergachev, Archaeol Sec, Acad Sci, Moldavian SSR. Comment: according to excavator (Dergachev, 1970), burial complex reveals some affinities with Usatovo cemetery. Cf earlier dates of Majaki (Mayaki) site belonging to Usatovo group: Bln-629: $4400 \pm 100(\mathrm{R}, 1970$, v 12, p 413); LE-645: $4340 \pm 65$ (R, 1970, v 12, p 131).

\section{LE-856. Borisovka, Odessa Obl, Ukrainian SSR}

$\mathbf{3 9 2 0} \pm \mathbf{5 0}$

Wood from pit-grave cover of Borisovka Kurgan, Tatrabunar Rayon. Depth, ca $3.5 \mathrm{~m}$ from summit of Kurgan; ca $2 \mathrm{~m}$ from present day surface. Coll and subm by B E Zolotun, Inst Agric, Kherson. Date agrees well with those of other sites belonging to Pit-Grave culture.

\section{Ukrainian SSR: Medieval sites}

\section{LE-887. Podrin, Volyn' Obl}

$$
1240 \pm 50
$$

Charcoal from cultural layer of Early Slavonic settlement of Podrin, Kovel'sk Rayon. Archaeol date: 8th century AD. Coll and subm by I P Rusanova, Inst Archaeol, Acad Sci, USSR, Moscow.

\section{LE-888. Buki, Zhitomir Obl}

$$
960 \pm 50
$$

Charcoal from cultural layer of Early Slavonic settlement of Buki, Zhitomir Rayon. Depth, 0.4m. Expected age: 8th century AD. Coll and subm by I P Rusanova.

\section{LE-886. Tselikov Bugor, Chernigov Obl}

$$
1130 \pm 50
$$
AD 820

Charcoal from burned dwelling No. 2, Tselikov Bugor settlement, Novgorod-Severski Rayon. Coll and subm by P N Tret'yakov, Inst Archaeol, Acad Sci, USSR, Leningrad.

\section{North Caucasus: Bronze age sites}

\section{LE-885. Verkhnegunib, Daghestan ASSR}

$3200 \pm 50$

\section{BC}

Charred wooden beams from roof of dwelling, Verkhegunib Early Bronze age settlement, Gunib Rayon. Excavation 5; depth, 0.65 to $0.75 \mathrm{~m}$. Presumed dating: Early Bronze age, end of 3rd-beginning of 2nd millennium BC. Coll and subm by V M Kotovich, Inst Hist, Lang \& Lit, Makhach-Kala. Comment: date is younger than expected.

\section{LE-948. Elista, Kalmyk ASSR}

$$
3930 \pm 90
$$

Charcoal from catacomb grave of Elista Kurgan cemetery, $2 \mathrm{~km} \mathrm{NE}$ of town of Elista. Depth, $5 \mathrm{~m}$ below summit of kurgan. Coll and subm by U E Erdyner, Inst Hist, Ling \& Lit, Kalmyk ASSR. Comment: date agrees well with dates of Catacomb culture sites in Rostov Obl: Bln-693: $3925 \pm$ 
160; Bln-694: $4215 \pm$ 100; Bln-696: $4005 \pm$ 100; Bln-697: $4065 \pm 120$ (R, 1970, v 12, p 414-415).

Central Asia: Mesolithic and Bronze age sites Uzbek SSR

\section{LE-982. Machai Cave, Surkhan-darya Obl \\ $7550 \pm 100$}

Charcoal from Machai cave, Baisun Rayon. Depth, 1.1m; presumed Mesolithic age; Mesolithic tool assemblage. Coll and subm by U Islamov, Inst Archaeol, Samarkand. Comment: date is older than early Neolithic assemblages of Djeytun (Dzheytun) and Ghissar (Hissar) cultures of Central Asia.

\section{LE-916. Sapalli-tepe, Surkhan-darya Obl}

$3640 \pm 90$

Mound of Sapalli-tepe, Gagarin Rayon. Charcoal from rubbish in ceramic stove; $1.5 \mathrm{~m}$ below surface. Coll and subm by A Askarov, Inst Hist, Acad Sci, Uzbek SSR, Samarkand. Comment: site is attributed to transition from Namazga V to Namazga VI periods. Correspondingly, date is older than those of Namazga VI (Cf Ulug-Depe, and Dashly, this list). Namazga V period is dated at Altyn-Depe: Bln-716: $4120 \pm 100$; Bln-717: $4025 \pm 100$ (R, 1970, v 12, p 417-418).

\section{Kuyuk-tepe series, Namagan Obl}

Kuyuk-tepe settlement is in Uch-Kurgan Rayon. Archaeol date, 1st to 7 th centuries AD. Coll and subm by N G Gorbunova, State Hermitage Mus, Leningrad (Gorbunova et al, 1971).

\section{LE-873. Kuyuk-tepe}

$$
1590 \pm 50
$$

Charcoal; depth, $2.6 \mathrm{~m}$.

LE-879. Kuyuk-tepe

$$
1500 \pm 50
$$

Wood, depth, $4.55 \mathrm{~m}$.

\section{LE-880. Kuyuk-tepe}

Charcoal; depth, $2.20 \mathrm{~m}$.

$$
\begin{array}{r}
1320 \\
\text { AD } 630
\end{array}
$$

\section{LE-881. Kuyuk-tepe}

$$
1480 \pm 40
$$

Charcoal; depth, $1 \mathrm{~m}$.

\section{Turkmenian SSR}

\section{LE-980. Ulug-Depe}

Ulug-Depe mound, near Dushak, ca 180km SE of Ashkhabad. Charcoal; depth, $0.5 \mathrm{~m}$ below surface. Early Namazga VI period; 2nd half 2nd millennium BC. Coll and subm by V M Masson, Inst Archaeol, Acad Sci, USSR. Comment: date close to those obtained for Namazga VI, Dashly 
series, Afghanistan, below, and older than date for late Namazga VI, Namazga-Tepe: Le-665: $2980 \pm 60$ (R, 1970, v 12, p 142).

Kazakh ASSR, Urals, and Western Siberia: Bronze age

Andronovo culture series

\section{LE-989. Novo-Nikol'skoye I, N Kazakh Obl 1210 BC}

Charcoal from cultural layer of Novo-Nikol'skoye I settlement. Excavation 4; depth, 0.6 to $0.8 \mathrm{~m}$ below surface. Archaeol date: middle 2nd millennium BC. Coll and subm by G B Zdanovich, North Kazakh Hist Mus.

\section{LE-990. Amangal'dy I cemetery, N Kazakh Obl $\quad \mathbf{1 7 8 0} \pm \mathbf{8 0}$}

Wood from grave pit of Kurgan 8; depth, 0.6 to $0.8 \mathrm{~m}$, Amangal'dy cemetery, Lenino Rayon. Presumed age: Bronze, 15th-17th century BC; Andronovo culture. Coll and subm by G B Zdanovich.

\section{Alakul' cemetery sub-series}

\section{LE-924. Alakul' cemetery}

Wood from Kurgan 15, Grave 1.

\section{$1410 \mathrm{BC}$}

\section{$1430 \pm 80$}

LE-923. Alakul' cemetery

AD 520

Wood from Kurgan 15, Grave 6. Alakul' cemetery is situated in Kurgan Obl. Archaeol dating: Andronovo culture: 2nd millennium BC. Comment: LE-923 is much more recent than expected. Coll and subm by E E Kuz'mina, Inst Archeol, Acad Sci, USSR, Moscow.

\section{South Urals sub-series}

\section{LE-1016. Lipovaya Kur'ya, Chelyabinsk Obl 1100 вС}

Charcoal from dwelling of Lipovaya Kur'ya settlement, Miass Rayon; depth, ca $1 \mathrm{~m}$ below surface. Subm by L P Khlobystin, Inst Archeol, Acad Sci, USSR. Earlier date: LE-633: $3590 \pm 90$ (R, 1970, v 12, p 145).

Wood from Kurgan 26, Grave 1; depth $0.98 \mathrm{~m}$ below surface.

\section{LE-921. Tuktubayevo cemetery}

Wood from Kurgan 26, Grave 2; depth $1.15 \mathrm{~m}$ below surface. Comment: Tuktubayevo cemetery is culturally attributed to Fedorovo stage of Andronovo culture of South Urals area. Samples coll and subm by E E Kuz'mina. 


\section{Yelovka II sub-series}

LE-940. Yelovka II, Tomsk Obl

$3060 \pm 65$

Wood (facing and cover) from Grave 64; depth, $0.9 \mathrm{~m}$ below surface.

\section{LE-939. Yelovka II}

$3150 \pm 55$

Wood (facing) from Grave 112; depth, $0.7 \mathrm{~m}$ below surface. Yelovka II cemetery is situated in Kozleonikov Rayon. Samples coll and subm by V I Matyushchenko, Tomsk State Univ.

\section{Dashly series}

$$
\text { Afghanistan }
$$

Group of mounds, N of Akcha, N Afghanistan.

LE-976. Dashly 1

$3200 \pm 45$

Charcoal from Dashly 1 site. Excavation 1; Dwelling 18; depth, $1.05 \mathrm{~m}$ below surface.

\section{LE-975. Dashly 1}

$3520 \pm 45$

Charcoal from Dashly 1. Excavation 1; Dwelling 24; depth, 1.1m.

\section{LE-977. Dashly 2}

$3340 \pm 45$

Charcoal from Dashly 2 site. Test Pit 1; depth, $10 \mathrm{~m}$ below surface.

\section{LE-978. Dashly 3}

$3440 \pm 50$

$1490 \mathrm{BC}$

Charcoal from excavation wall; depth, $0.55 \mathrm{~m}$ below surface. Comment: all samples originate from deposits culturally attributed to Namazga VI period (Kruglikova \& Sarianidi, 1971). There is satisfactory agreement among these dates as well as with other dates of Namazga VI sites (Cf LE-916 -980, above). Samples provided by Soviet-Afghan Archaeol Expedition; coll and subm by V I Sarianidi, Inst Archeol, Acad Sci, USSR, Moscow.

\section{REFERENCES}

Berger, Rainer and Libby, W F, 1968, UCLA radiocarbon dates VIII: Radiocarbon, v 10, p 402-416.

Bryusov, A Ya, 1952, Notes on the history of the tribes of the European USSR in the Neolithic: Moscow, Izd Akad nauk SSSR (in Russian). Burov, G M, 1972, Archaeological sites in the valley of the Upper Sviyaga: Ul'yanovsk
(in Russian).

* Cherdyntsev, V V, et al, Geological Institute radiocarbon dates II: Radiocarbon, v 10, p 426-436.

Chernyavski, M M, 1971, The Neolithic of northeastern Belorussia: Minsk (in Russian).

Dergachev, V A, 1970, The study of Bronze age sites in Moldavia, in: Rybakov, B A (ed), op cit, p 352 (in Russian).

Dikov, I I and Raushenbakh, V M, 1970, Investigations of Neolithic and Bronze age sites in Moscow and Vladimir Oblasts, in: Rybakov, B A (ed), ibid, p 53-54 (in
Russian).

Doluchanov [Dolukhanov], P M, 1973, Die Spiegelschwankungen der Ostsee und der Seebecken im nord-ostbaltischen Raum während des Holzäns: Petermanns Geog
Mitt, v 117, p 169-179. 
Dolukhanov, P M and Timofeyev, V I, 1970, Investigations at Tsedmar D site, in: Rybakov, B A (ed), op cit, p 13-14 (in Russian).

*Dolukhanov, P M et al, 1970, Radiocarbon dates of the Institute of Archaeology II: Radiocarbon, v 12, p 130-155.

Gorbunova, V G et al, 1971, Investigations of the Fergana Expedition, in: Rybakov, B A (ed), op cit, p 404-405 (in Russian).

Ilves, E, Punning, J M, and Liiva, A, 1970, Tartu radiocarbon dates IV: Radiocarbon, $\mathrm{v} 12, \mathrm{p} 238-241$.

Kohl, G and Quitta, H, 1970, Berlin radiocarbon measurements IV: Radiocarbon, v 12, p 400-420.

Krizhevskaya, L Ya, 1971, Investigations of the Steppe Neolithic Expedition, in: Rybakov, B A (ed), op cit, p 100 (in Russian).

1972, Stone tools from the Neolithic site of Matveyev Kurgan II: Kratkiye soobshcheniya Inst Arkheol, Akad nauk SSSR, 131, p 123-128 (in Russian).

Kruglikova, I T and Sarianidi, V I, 1971, Ancient Bactria in the light of new archaeological discoveries: Sovetskaya arkheol, no. 4, p 154-177 (in Russian).

Loze, I A, 1970, New discoveries by the Lubana Expedition, in: Rybakov, B A (ed), op cit, p 326 (in Russian).

Miklyayev, A M, 1971, Stone and Bronze age sites in the upper Western Dvina basin: Leningrad (in Russian).

Miklyayev, A M and Minosyan, R S, 1970, Work of the Northwestern Expedition of the State Hermitage Museum, in: Rybakov, B A (ed), op cit, p 3-4 (in Russian).

Oshibkina, S V, 1966, Modlona site: Its origin and relationship to the Kargopol' culture: Sovetskaya arkheol, no. 4, p 37 (in Russian).

Punning, J M, et al, 1971, Tartu radiocarbon dates V: Radiocarbon, v 13, p 78-83.

Rimantene, R K, 1970, Investigation of the Stone age site at Sventoji [Shvyantoyi], Krestinga Rayon, in: Rybakov, B A (ed), op cit, p 313-314 (in Russian).

Rybakov, B A (ed), 1970, Arkheologicheskiye otkrytiya 1969g (Archaeological discoveries 1969): Moscow, Izd "Nauka” (in Russian).

1971, Arkheologicheskiye otkrytiya 1970g: Moscow, Izd "Nauka" (in Russian). sian).

*Semyontsov, A A, et al, 1972, Radiocarbon dates of the Institute of Archaeology III: Radiocarbon, v 14, p 336-367.

*Shimkin, D B and Shimkin, E, 1974, 16 Sites in the Soviet Union: Field Research Proj, Microfiche No. 12, p 1-8, Coconut Grove, Miami, Florida.

Sulija [Shuliya], K S, 1968, The first radiocarbon datings for archaeological sites in Lithuania: Materialy konferentsiyi molodnykh uchyonykh Litvy (Materials of the conference of young scientists of Lithuania): Vilnius (in Russian).

Vankina, L V, 1970, Sārnate, a peat bog campsite: Riga (in Russian).

Vogel, J C and Waterbolk, H T, 1963, Groningen radiocarbon dates IV: Radiocarbon, v 5, p 163-202.

Zagorskis, F A, 1967, The Early and Mature Neolithic in the E part of Latvia: Riga (in Russian).

Zayets, I I, 1973, Excavations at the Tripol'ye site of Klishchev, on the Southern Bug, in: Rybakov, B A (ed), op cit, p 282 (in Russian).

* Part of our series received from Academician Keldysh. 